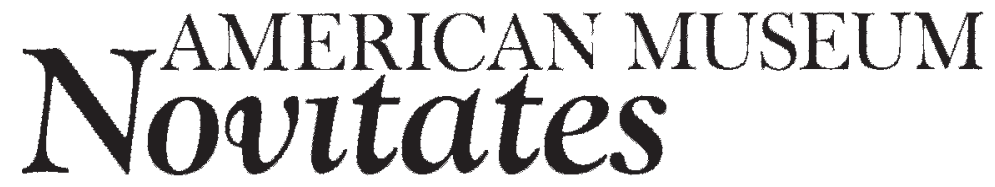

PUBLISHED BY THE AMERICAN MUSEUM OF NATURAL HISTORY CENTRAL PARK WEST AT 79TH STREET, NEW YORK, NY 10024 Number 3580, 17 pp., 5 figures, 1 table

September 6, 2007

\title{
First Jurassic Triconodont from South America
}

\author{
GUILLERMO W. ROUGIER, ${ }^{1,2}$ ALBERTO GARRIDO ${ }^{3}$ LEANDRO GAETANO, ${ }^{4}$ \\ PABLO F. PUERTA, ${ }^{5}$ CYNTHIA CORBITT, ${ }^{6}$ AND MICHAEL J. NOVACEK ${ }^{7}$
}

\begin{abstract}
A new mammal from the Middle Jurassic Cañadon Asfalto Formation, Patagonia, Argentina, is reported. The specimen, an isolated lower? molariform, is erected as the type of a new genus and species of triconodont, Argentoconodon fariasorum. The molariform presents a peculiar combination of primitive and derived features that makes recognition of its affinities challenging. Argentoconodon shares similarities with poorly known triconodonts from the Jurassic of North America and Morocco and lacks the diagnostic traits of the triconodontid triconodonts. Argentoconodon resembles in general the paraphyletic "amphilestid" triconodonts. The specimen is too incomplete to warrant broader interpretations, but it suggests that at least this lineage of South American mammals was distinctly autapomorphic, perhaps with an origin in forms with a broader geographical distribution.
\end{abstract}

\section{INTRODUCTION}

The presence of Jurassic mammals in South America has long been known, or at least presumed, based on the description by Casamiquela (1964) of Ameghinichnus patagonicus, an ichnofossil from the Jurassic La
Matilde Formation (Callovian-Oxfordian) of Santa Cruz province, Argentina. In the type locality, several trackways are known for this ichnogenus that represent several locomotory modes ranging from galloping to asymmetrical gait (Casamiquela, 1964; Rainforth and Lockley, 1996; Leonardi, 1994). Ameghini-

\footnotetext{
${ }^{1}$ Department of Anatomical Sciences and Neurobiology, University of Louisville, Louisville 40292, KY (grougier@ louisville.edu).

${ }^{2}$ Research Associate, Division of Paleontology, American Museum of Natural History.

${ }_{3}^{3}$ Museo Municipal Carmen Funes, Plaza Huincul, 8318 Neuquén, Argentina (algene@copelnet.com.ar).

${ }^{4}$ Museo Argentino de Ciencias Naturales Bernardino Rivadavia, 1405 Buenos Aires, Argentina (leandrocg1@gmail. com).

${ }^{5}$ Museo Paleontológico Egidio Feruglio, 9100 Trelew, Argentina (ppuerta@mef.org.ar).

${ }^{6}$ Department of Biology, University of Louisville, Louisville 40292 (cynthia.corbitt@louisville.edu).

${ }^{7}$ Division of Paleontology, American Museum of Natural History, New York 10024 (novacek@amnh.org).
} 
chnus ichnofossils were attributed to "pantotheres" by Casamiquela (1964) and to multituberculates by Kielan-Jaworowska and Gambaryan (1994). Olsen (1980) described a series of ichnofossils from the Lower Jurassic Newark supergroup as belonging to unidentified cynodonts; he later recognized these tracks as representing several species of Ameghinichnus (Olsen et al., 2002), and he referred to them as possible tritheledontids. Ichnofossils from North America are much larger than those from Patagonia and bring into question the original identification of those ichnites as mammalian. The status of Ameghinichnus is therefore uncertain at present. Footprints of advanced cynodonts or early mammals with hair impressions, however, have been recorded in the Triassic Stomberg group (Ellenberger, 1972, 1974, 1975).

Despite encouraging ichnological finds in Patagonia, Jurassic osteological remains of South American mammals have eluded paleontologists until recently (Rauhut et al., 2002; Forasiepi et al., 2004a, 2004b; Rougier and Apesteguia, 2004; Martin et al., 2005; Rougier et al., 2007), when Asfaltomylos patagonicus from the Middle Jurassic Cañadon Asfalto Formation was described and other probably related forms as yet undescribed were presented. Asfaltomylos has been described as a basal member of a recently erected group, the Australosphenida (Luo et al., 2001, 2002; Rougier et al., 2007), that would encompass mostly Mesozoic groups from the southern continents (Australia, South America, and Africa in particular) and potentially could represent the stem lineage of monotremes (see Rich et al. [2002], Woodbourne [2003], and Woodburne et al. [2003] for an opposite point of view).

Triconodonts are relatively widespread geographically and temporally, being major components of the Jurassic Holartic communities and still important during the Early Cretaceous (Cifelli et al., 1998; Rougier et al., 2001; Li et al., 2003; Meng et al., 2003; Hu et al., 2005). Occurrence of triconodonts in a general sense (i.e., any mammaliaform with a molariform crown dominated by a longitudinal series of three major cusps) in South America's Mesozoic has been proposed
(Bonaparte, 1986a, 1992) but the identification is problematic (see below). We report herein on a new triconodont from the Jurassic Cañadon Asfalto Formation, Chubut, Argentina, that shows all of the definitive features of triconodonts. This new triconodont highlights how precarious is our knowledge of the early Mesozoic mammalian faunas in South America and affords new possibilities for comparing the faunal development of the South American mammalian communities during the Mesozoic.

There is significant overlap and ambiguity among the terms collectively used to describe early mammaliamorphs. We use the term triconodont to refer to any mammaliamorph with three major crown cusps mesiodistally aligned; this term, as defined here, does not correspond to a monophyletic unit (Rougier et al., 1996, 2001; Hu et al., 1997, 1998; Ji et al., 1999; Luo et al., 2001, 2002, 2003: KielanJaworowska et al., 2004) and is used simply for ease of reference. The term triconodontid is used strictly for the members of the monophyletic clade Triconodontidae (Kermack, 1963; Crompton and Jenkins, 1979; Rougier et al., 1996, 2001; Cifelli et al., 1998; Ji et al., 1999; Kielan-Jaworowska et al., 2004). Amphilestidae is an assemblage of triconodonts (Kielan-Jaworowska and Dashzeveg, 1998; Sigogneau-Russell, 2003; KielanJaworowska et al., 2004, Rougier et al., in press) that in most recent phylogenetic proposals results in a non monophyletic grouping (Ji et al., 1999; Rougier et al., 2001; Luo et al., 2001, 2002); however, Kielan-Jaworowska et al. (2004) recovered some of the traditional members of Amphilestidae and some of the traditional members of Triconodontidae as a monophyletic unit they dubbed Eutriconodonta following earlier uses (Kermack et al., 1973). We think this arrangement unlikely and refer to amphilestids informally as those triconodonts traditionally included as such in the homonymous family, which usually shows three main cusps and two cingular cusps arranged fairly symmetrically and have a clear dominance of a cusp A/a (Simpson, 1928, 1929; Patterson, 1956). As employed here, the term has only practical reference value. Systematic terms such as Mammalia, Theria, and others follow phylogenetic definitions 


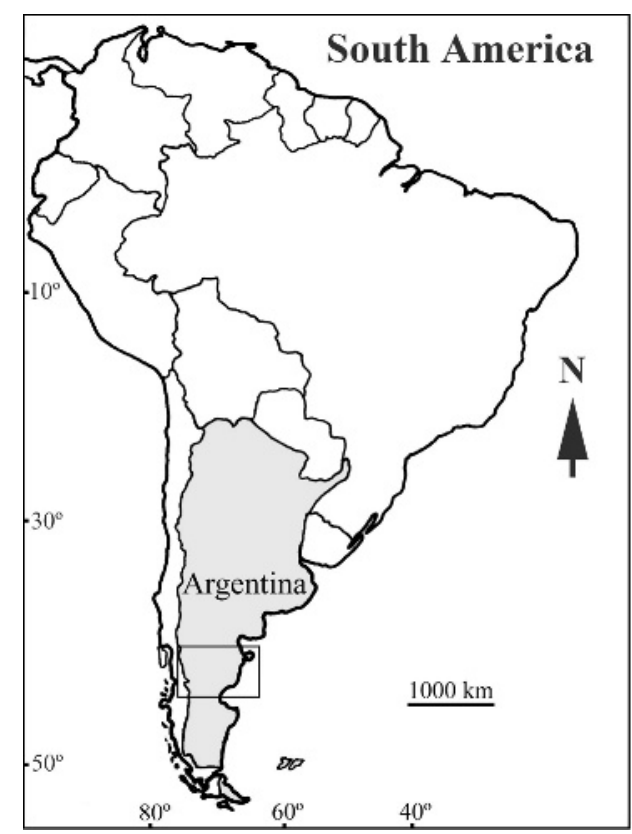

\section{Chubut Province}

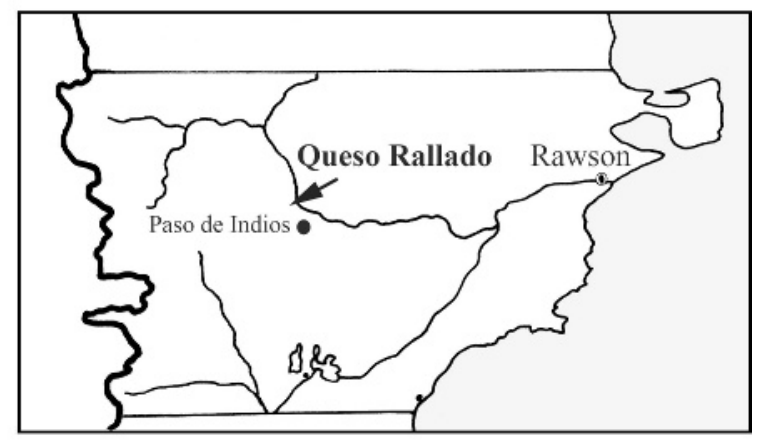

Fig. 1. Map indicating the location of the Queso Rallado locality, Chubut province, Argentina. Modified from Rougier et al., 2007.

(Rowe, 1988, 1993; Rougier et al., 1998). Triconodont cusp nomenclature follows the convention proposed by Crompton and Jenkins (1968) and recent reformulations, such as Rougier et al. (2003).

\section{GEOLOGICAL BACKGROUND}

The Cañadón Asfalto Formation (Stipanicic et al., 1968), of probable Callovian-Oxfordian age (Stipanicic et al., 1968; Tasch and Volkheimer, 1970; Musacchio et al., 1990), is extensively exposed in several localities of Chubut Province, Argentina, along the middle valley of the Chubut River (fig. 1). Paleontological prospecting of this formation has been centered around the village of Cerro Cóndor where exposures are accessed relatively easily. The vicinity of Cerro Cóndor has become a classic locality following Bonaparte's pioneering work in the area (Bonaparte, 1979, 1986b). The lithological constitution of the Cañadón Asfalto Formation combines a series of calcareous, silicoclastic, and volcanic deposits developed during the rifting and filling stage of the small Cañadón Asfalto Basin (Figari and Courtade, 1993; Figari et al., 1996).
Two subunits separated by a discordance were recognized by some workers within this sequence (Musacchio et al., 1990; Proserpio, 1987; Figari and Courtade, 1993); however, the passage from the lower to the upper part of the section is interpreted here as a lithological transitional change due to the progradation of a fluvial system with a north-tonorthwest direction over the lacustrine system in the area of Cerro Cóndor village.

The lower Las Chacritas Member (Silva Nieto et al., 2003), of approximately 250-m thickness, is composed of carbonate deposits, biohermal bodies, and black bituminous shales developed in broad lacustrine basins. The sporadic intercalation of basaltic flows, pyroclastic sediments, and mudflows indicates the presence of contemporaneous but intermittent volcanism, related to the evolution of the sedimentary basin.

The upper Puesto Almada Member (Silva Nieto et al., 2003) has a thickness of $270 \mathrm{~m}$ in the Cerro Cóndor area. It is characterized by an association of sandstones, siltstones, and tuffs intercalated by thin levels of limestones and conglomeratic lenses. This sedimentary succession is interpreted as a perilittoral flood 
plain and meandering fluvial deposits associated with small, shallow, and transient lacustrine bodies. The sporadic presence of pyroclastic material in the succession suggests the occurrence of intermittent ash fall episodes.

The Cañadón Asfalto Formation deposits have provided several vertebrates; among them, and besides the already mentioned Asfaltamylos, are fishes (Tharria feruglioi Bordas, 1942; Oligopleurus groeberi Bordas, 1942; and Luisiella inexcutata Bocchino, 1967); the sauropods Patagosaurus fariasi (Bonaparte, 1979; Rauhut, 2003), Volkheimeria chubutensis (Bonaparte, 1979), and Tehuelchesaurus (Rich et al., 1999); and the theropods Piatnitzkysaurus floresi (Bonaparte, 1979) and Cóndorraptor currumilii (Rauhut et al., 2002). Recent fieldwork in the area has also provided isolated elements of anurans, pterosaurs, and turtles. Invertebrates are represented by gastropods (Potamolithus Musacchio, 1995) and freshwater bivalves (Palaeomutela Turner, 1983).

All of the mammalian specimens collected in the Cañadon Asfalto Formation (Rauhut et al., 2002; Forasiepi et al., 2004a, 2004b; Martin and Rauhut, 2005) were recovered from the Queso Rallado locality, ca. $5.5 \mathrm{~km}$ NW of the Cerro Cóndor village. The fossiliferous level is situated in the middle part of the Las Chacritas Member, ca. $110 \mathrm{~m}$ from the base of the Cañadón Asfalto Formation (fig. 2). The bone-bearing bed forms a subtabular and irregular 50-cm-thick body intercalated in a thick, strongly deformed succession of tuffs, tuffaceous rocks, and thin basalt flows. The bone layer is composed of thin interlaminated calcareous and tuffaceous deposits rich in conchostracans and intercalated by irregular opal veins. According to our observations, the bonebearing deposits would have originated in a relatively small, shallow lacustrine body placed in a supralittoral environment adjacent to the main water body of the basin. A certain amount of transportation is evident in most of the specimens, which in general are represented by isolated elements; in a few instances, however, some association is preserved and several elements belonging to one individual are found in close proximity to each other, including occasionally partial skeletons of small to mid-sized vertebrates. We think the mammalian specimens floated into the body of water as complete skeletons from the nearby area and sank to the bottom of the small body of water where in most instances the skeletons were disturbed, resulting in a preponderance of isolated elements over relatively articulated skeletons.

\section{SYSTEMATIC PALEONTOLOGY}

CLASS MAMMALIA LINNAEUS, 1758

ORDER THERIIMORPHA ROWE, 1993

\section{Argentoconodon, new genus} figures 3,4

Type and Only Species: Argentoconodon fariasorum, new species.

ETymology: Argento, from Argentina, the country were the holotype was found; and con odon, from the Greek "conical tooth", in reference to the conical aspect of the cusp of the first described triconodonts, and now a common ending of triconodont names. The species name fariasorum is from Farias, after Ricardo Farias and his family, who have supported paleontological research on their land for decades. They have been gracious hosts who greatly facilitated our work. Our knowledge of the continental Jurassic in Argentina owes much to their longstanding support.

Diagnosis: Generic and specific diagnoses are the same because only one species is known. "Amphilestid" with a pentacuspid lower molar consistent of three main cusps b, a, c and small anterior and posterior cusps. All cusps are recurved to some degree and a small accessory cusp is present lingual to the notch between cusps a and $\mathrm{c}$ in the position of $\mathrm{g}$ (Kuehneocone of morganucodonts). Cusps $\mathrm{b}$ and $\mathrm{c}$ are subequal in height. Accessory cusps e and d extend mesially and distally (respectively) from the crown base. Interdental contact is in echelon. The crown is extremely compressed buccolingually.

PRovenance: The holotype is housed in the Museo Paleontólogico "Egidio Feruglio" (MPEF) in Trelew (Province of Chubut), Argentina, and bears the collection number MEF-PV 1877. The specimen was collected in March 2003 at the local school in Cerro Cóndor by breaking assorted blocks from the Queso Rallado locality $\left(43^{\circ} 24^{\prime} 33.55^{\prime \prime} \mathrm{S}, 69^{\circ} 13^{\prime} 50.1^{\prime \prime} \mathrm{W}\right)$, 


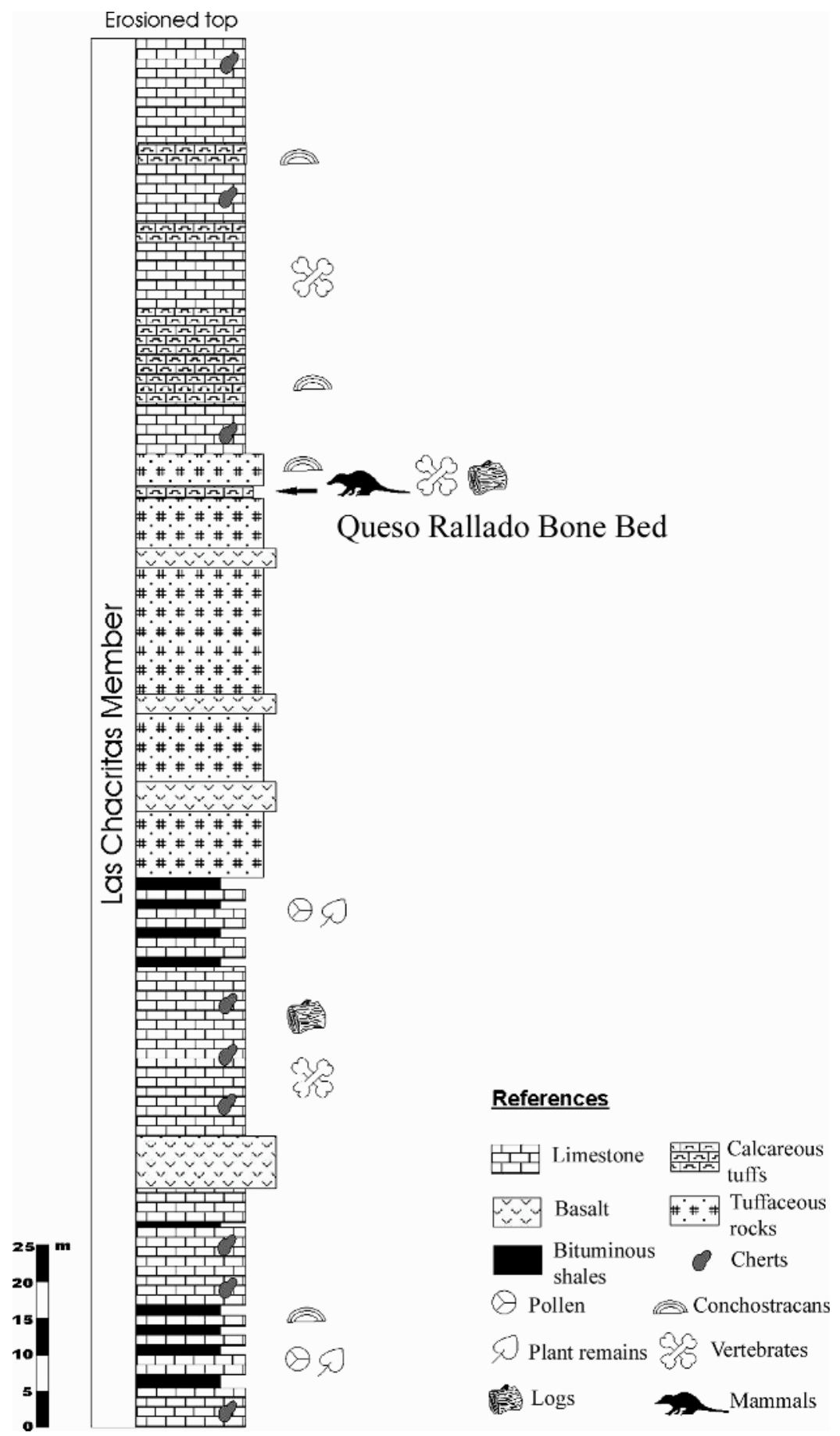

Fig. 2. Reconstructed lithological section of the Queso Rallado locality (by A.G.), Las Chacritas Member, Cañadón Asfalto Formation, sensu Silva Nieto et al. (2003). 


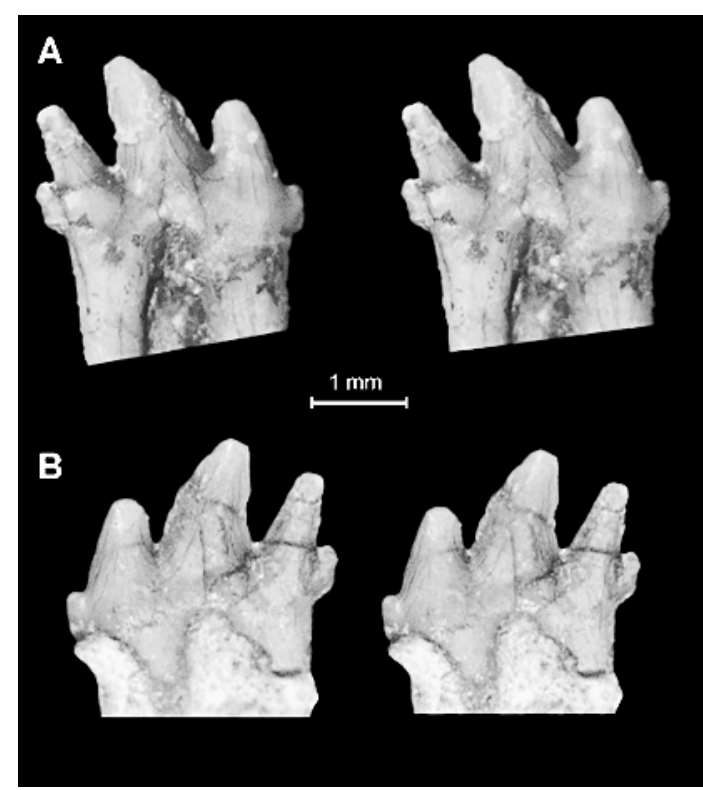

Fig. 3. Stereophotographs of Argentocondon fariasorum (MPEF PV 1877) in labial (A) and lingual (B) views.

about $5.5 \mathrm{~km}$ west-northwest of the village of Cerro Cóndor (Bonaparte, 1979, 1986b; Rauhut et al., 2002; Martin and Rauhut, 2005), in Chubut Province, Argentina.

Associated Fauna: Vertebrates at the Queso Rallado locality mainly occur as isolated elements of small to mid-sized animals; articulated or associated remains are present, although scarce. The vertebrate fauna of the Queso Rallado seem to represent a composite of aquatic and terrestrial animals in agreement with littoral lacustrine sedimentary conditions inferred from the fossil-bearing strata at Queso Rallado. Small aquatic basal turtles, anurans, and crocodiles dominate numerically; fish elements and other aquatic vertebrates are far more scarce. Terrestrial vertebrate elements are relatively rare and are represented by sphenodontians, pterosaurs, dinosaurs (teeth), and mammals.

\section{DESCRIPTION}

The specimen is a complete isolated molar or molariform, interpreted here as a lower? right tooth, of a likely mid-row position; that is, it is neither the first or the last molariform. Because
South American Mesozoic mammals have consistently proven to be difficult to compare with mammals from other regions of the globe, and by the fact that the morphology of the molar has details that would be unusual in lower teeth, we consider it possible that MEF PV 1877 is in fact an upper molar instead of a lower molar as interpreted here.

The molar is relatively large (see fig. 3A, B), close to $3 \mathrm{~mm}$ in length (see figs. $3 \mathrm{~A}, 3 \mathrm{~B}, 5$, and appendix 1), extremely compressed, and bears tall gracile cusps. The crown is dominated by three large cusps $(\mathrm{a}-\mathrm{c})$ that are flanked mesially and distally by well-defined cingular cusps e and d. Determination of the nature of the molariform (upper or lower, left or right) is not simple. There are virtually no cingula, and the cusps are almost fully symmetrical in buccolingual view (fig. 3A, B). The main elements helping to decide these factors are: (1) there is a small amount of wear on one side of cusp b, but this could also be a small chip of enamel (fig. 3); (2) there is a small cusp at the posterior end of the base of cusp a that can be interpreted as a remnant of a cingulum and is reminiscent of a cusp g, or Kuhneocone (Crompton, 1974; Sigogneau-Russell, 1983; Sigogneau-Russell and Godefroit, 1997); and (3) the position of the cingular cusps $(\mathrm{d}, \mathrm{e})$ suggests that the front of the tooth was slightly overlapped by the preceding tooth, the overlap occurs buccally among the mammals known to us and therefore suggests that this is the labial edge. These three arguments suggest that the buccal side of the specimen is to the right, as seen in occlusal view. Cusp c is slightly asymmetrical, curving lightly toward the side identified as buccal by the above arguments, which would be an unusual circumstance. This cusp may be deformed or broken, but it is not evident (figs. 3 and 4). This feature raises doubts with regard to the interpretation of this tooth as a lower molar.

The main features of the tooth are the five cusps aligned anteroposteriorly, identified here as cusps a-e. In occlusal view (fig. 4C), five aligned cusps (a-e) are clearly distinguished; the accessory cusp ( $\mathrm{g}$ ), however, is only a little bulge basal to cusp a, evident as a triangular-shaped elevation between cusps a and c. Cingular cusps (d-e) are placed slightly lingual to the main cusps $a-c$, 

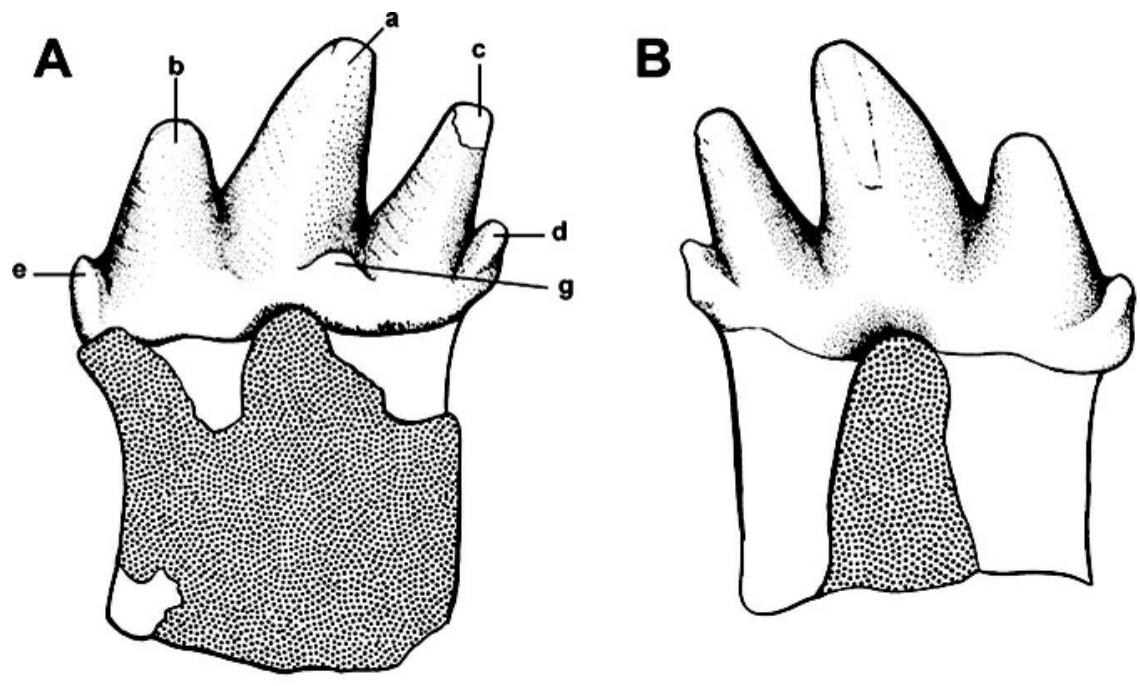

\section{C}
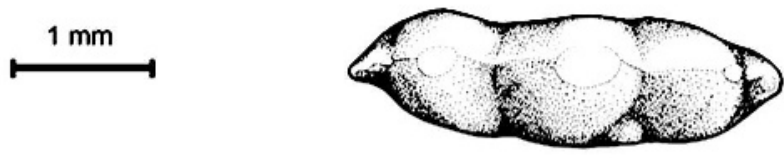

Buccal
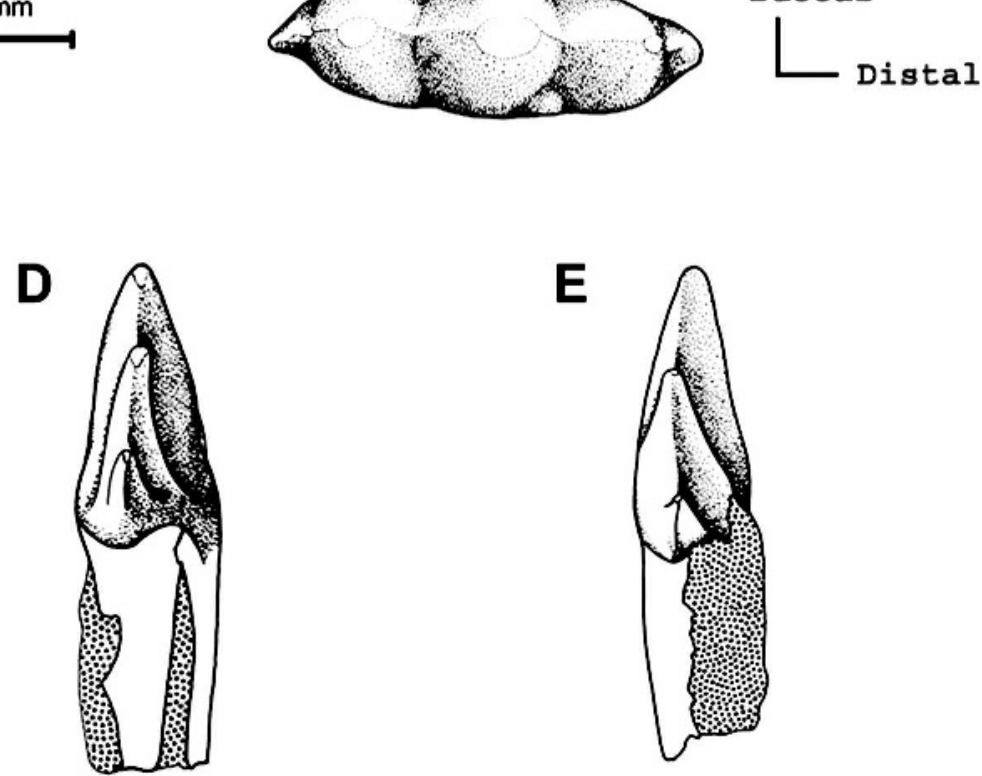

Fig. 4. Illustrations of Argentoconodon fariasorum (MPEF PV 1877) in lingual (A), labial (B), occlusal (C), distal (D), and mesial (E) views. Cusp nomenclature is after Crompton and Jenkins (1968).

although not enough to mask the essentially linear arrangement of cusps.

In labial view (fig. 4B), the major cusps are well rounded, almost conical, and neither cingula or wear is evident, except for the possible facet on the labial aspect of cusp b. The lingual aspects of the major cusps are slightly more flattened than the labial slopes.

Cusp a is dominant, centrally located between the two roots of the molariform, 
and pronouncedly recurved distally, with the lingual slope slightly more vertical than the bulging buccal side. Cusps $\mathrm{b}$ and $\mathrm{c}$ are of similar height (cusp c is slightly taller), but cusp b is substantially more robust than cusp c. Cusp b is separated from cusp a by a notch that is not carnassial and is placed in the middle of the long axis of the tooth, and therefore the occlusal view is symmetrical. Cusp b has a thick base that projects more dorsally than the base of cusp a (that is, the valley between $\mathbf{b}$ and $\mathbf{a}$ is shallower that that between $\mathbf{a}$ and $\mathbf{c})$. There is clear cingulum bordering mesially the base of cusp b, but it is only slightly inflated. Cusp b is more erect than either cusps a or c, and it is almost parallel to the longitudinal axis of the tooth. Cusp c is very thin, pointed, and perhaps has lost its very tip. A minute amount of sediment is still present on the lingual aspect of this cusp. Cusp c is recurved distally and is sharp and very thin. Two accessory cusps, $\mathrm{d}$ and e, are located at the posterior and anterior ends of the tooth, respectively; both of them are small and buccolingually compressed. Cusp $\mathrm{d}$ is taller than cusp e and has a very peculiar outline in lateral view, hanging posteriorly from the wall of the posterior root. The apex points posteriorly. Cusp e is very small, also basal, and, as with cusp d, is part of the interface between crown and root without defining a conspicuous cingulum. The apex of cusp e points mesially in a distinct way and also projects sharply from the mesial aspect of the root.

On the buccal aspect of cusp e there is a somewhat flattened surface that matches a similar area on the buccal area of cusp d, suggesting that the interlock between the successive molariforms was in echelon. This interpretation is reinforced by the lack of grooves for interlocking of the roots, or notched mesial and distal ends of the crown.

Except for the possible wear facet on the tip of cusp b, there are no clear wear facets present on the molariform.

A small cuspule is placed between the bases of the cusps a and c, more closely related to cusp a than to cusp c. This tiny cusp is borne lingual to the principal ones and its development does not exceed the base of cusps a and c, being so low that its tip does not reach the base of the embrasure between them. This cusp may represent the remnant of a cingulum but it is not connected per se to a distinct cingulum. The position of this cuspule is similar to the kuehnecone (g) of basal mammaliaforms and it is interpreted here as a homologue structure.

The molar has two fully separated roots that form a subcircular section, with the mesial root more robust and expanded than the distal one. As preserved, both roots are subequal in length, but the tip of the anterior root is broken, so it may have been longer than the posterior one.

\section{DISCUSSION AND COMPARISONS}

The informal group of triconodonts is usually regarded as a polyphyletic assemblage of probable monophyletic subunits including Morganucodontidae, Amphilestidae, Triconodontidae, and a variety of other mammaliaforms with dentitions dominated by the presence of three major cusps mesiodistally aligned (Rougier et al., 1996, 2001, 2003; Cifelli and Madsen, 1998; Kielan-Jaworowska and Dashzeveg, 1998; Cifelli, 2001; Luo et al., 2002; Sigogneau-Russell, 2003; KielanJaworowska et al., 2004). The comparisons below primarily address similarities and differences of Argentoconodon with triconodonts.

The new specimen differs from Morganucodon and allies in the presence of a cusp $\mathrm{b}$ that is part of the crown and not cingular, the lack of numerous well-developed cingular cusps, and the presence of similarly sized cusps $\mathrm{b}$ and $\mathrm{c}$. All of these traits are derived features shared by our specimen and more derived mammaliaforms, in particular amphilestids and derived triconodontids (Cifelli et al., 1998; Cifelli and Madsen, 1998; KielanJaworowska and Dashzeveg, 1998; Rougier et al., 2001).

Despite prima facie similarities, Argentoconodon lacks any of the derived features of later triconodontids (Triconodontidae sensu stricto or eutriconodonts), in particular the Early Cretaceous representatives of this group. Derived triconodontids have all principal cusps $(\mathrm{a}-\mathrm{c})$ and the posterior cingular cusp (d) of similar height, and the molar interlocking is produced by a groove present 
on the mesial face of the anterior root of the molariforms that lodges cusp $\mathrm{d}$ of the preceding molar (Cifelli and Madsen, 1998; Rougier et al., 2001; Luo et al, 2002, KielanJaworowska et al., 2004). Among more basal triconodontids, such as Priacodon (Simpson, 1929; Rasmussen and Callison, 1981; Krusat, 1989), the groove on the mesial aspect of the molariform root is absent, and cusp $d$ is distinctively smaller than cusps a-c. Despite the plesiomorphic nature of Priacodon, this form is nonetheless a basal member of the triconodontid radiation (Simpson, 1925a, 1925b, 1929; Rougier et al., 1996, 2001; Ji et al., 1999; Luo et al., 2002; Kielan-Jaworowska et al., 2004). Specifically, lower molars of Priacodon differ from our specimen in having cusp b taller than cusp c, in lacking cusp e, and in having non posteriorly recumbent cusps and a molar less buccolabially compressed.

A degree of uncertainty is unavoidable when the material basis consists of a single isolated molariform; however, the affinities of the Patagonian specimen clearly lie among the more derived triconodonts, amphilestids in particular. Argentoconodon shares with amphilestid lower molars the following derived features: teeth pentacuspid and roughly symmetrical mesiodistally; cusps $\mathrm{b}$ and $\mathrm{c}$ of subequal height and shorter compared to the principal cusp a; labiolingually compressed molars in comparison to morganucodontids; cusp e present and large (subequal to cusp d); and lacking, or greatly reduced, lingual cingulum and accessory cusps greatly reduced or absent. Some of theses features, like the relative height of the cusps are primitive characters and likely lack any phylogenetic information at this systematic level and underline the paraphyletic nature of "amphilestids" in general.

Compared to the Middle Jurassic Amphilestes (Owen, 1871; Simpson, 1928; personal obs.), the tooth described here is similar in the general arrangement of the principal cusps and in having cusps $\mathrm{d}$ and e of comparable height. On the other hand, Amphilestes (Simpson, 1928, Sigogneau-Russell, 2003) differs from the Patagonian specimen in having a nonrecumbent cusp a, symmetrical cusps $b$ and $c$ that are much less developed than cusp a, and a welldeveloped lingual cingulum.
Argentoconodon is similar to the Bathonian amphilestid Phascolotherium bucklandi in the transverse cusp compression and in having cusps $\mathrm{d}$ and $\mathrm{e}$ of similar development. However, in $P$. bucklandi cusp b is similar in height to cusp c, and a well-developed lingual cingulum is formed by a continuous thickening; these features are unlike those of Argentoconodon. Both Amphilestes and Phascolotherium show a basal labial bulging of the base of cusp a, which is missing or very poorly developed in Argentoconodon. Most amphilestids show this bulging developed to a certain degree, and it has been regarded as characteristic of the group (Simpson, 1928, 1929). The asymmetry in the buccolabial section of cusp a created by this bulging is what, in conjunction with the occlusion mode, has led to the consideration of amphilestids as having incipiently triangular molariforms that could represent intermediate stages toward the full acquisition of triangular or "therian" molariforms (Vandebroek, 1964; Mills, 1971; Starck, 1995).

The Patagonian tooth differs from the Late Jurassic amphilestids from the Morrison Formation (United States) Comodon (Simpson, 1925b; Kretzoi and Kretzoi, 2000; Cifelli, 2002) and Aploconodon (Simpson, 1929; Kretzoi and Kretzoi, 2000). In the former, cusp e is lacking and in its place is cusp f; it has a lingual cingulid and cusp $b$ is more developed than cusp c, which are both very short compared to cusp a. Overall, Comodon is similar to Tendagurodon (see below). Argentoconodon is also different from Aploconodon comoensis, an amphilestid from the Late Jurassic of the United States, which has no cusps $\mathrm{d}-\mathrm{f}$ except for the last molar that shows cusp e. These Jurassic amphilestids from North America, Aploconodon and Comodon, with denudated crowns and simplified patterns seem to be related to later Asiatic amphilestids from Asia (Rougier et al., 1999, 2001).

Jeholodens jenkinsi was originally described as a triconodontid ( $\mathrm{Ji}$ et al., 1999), but recent studies identify this form as a likely basal amphilestid (Rougier et al., 2001; Rougier et al., in press). Jeholodens differs from the molar described here in having cusps erect and not as compressed as those of the Patagonian molar. 
Jeholodens, as with most primitive triconodontids, has a well-developed cusp e (reported as absent by Ji et al., 1999; see Rougier et al., 2001) and, despite its juvenile condition (several antemolar elements are still in the process of eruption), shows a typical amphilestid alternate occlusion, somewhat similar to the one present in later therians, instead of the one-to-one mode characteristic of triconodontids (Crompton, 1971, 1974; Crompton and Jenkins, 1979).

The amphilestid Klamelia (Chow and Rich, 1984) from the Late Jurassic of China differs from the molariform presented here because it has asymmetrical tooth crowns with cusp a not centered in occlusal view and a weak lingual cingulid. It is also different because of the presence of a cingulum that includes a poorly developed cusp b. If our interpretation of the interdental contact of Argentoconodon is correct, Klamelia and Argentoconodon share the partial overlapping or "echelon" contact between two successive teeth. This condition is not widespread among triconodonts (see Kielan-Jaworowska et al., 2004).

Gobiconodontids are a very autapomorphic group of triconodont mammaliamorphs that have been considered to be related to amphilestids (Trofimov, 1978; Jenkins and Schaff, 1988; Kielan-Jaworowska and Dashzeveg, 1998) and, with reservations, to triconodontids (Rougier et al., 2001; Wang et al., 2001; Luo et al., 2002; Meng et al., 2003). The molar described here shows many differences from Gobiconodontidae molariforms and closely related forms such as Repenomamus ( Li et al., 2000; Wang et al., 2001; Meng et al., 2003), notwithstanding the fact that some of the characteristics that diagnose this group are not available in our specimen (e.g., characters of the upper dentition and tooth formula). Argentoconodon and gobiconodontids are dissimilar in that gobiconodontids present a very distinct cusp f, possess carnassial notches, and the main cusps present a distinctive lanceolate profile. Gobiconodontids lack cingular cusps and do not have overlapping between successive molars.

Despite the paucity of the Gondwanan record of triconodonts, these few specimens are particularly relevant for comparisons with Argentoconodon. From the Late Triassic and
Jurassic of India a variety of tricondonts has been described and variously attributed to Morganucodontidae or Amphilestidae (Yadaggiri, 1984; Datta and Das, 1996, 2001; Prasad and Manhas, 2002). Among the teeth described as morganucodontids, Gondwanodon tapani (Datta and Das, 1996) shows, as does Argentoconodon, the relative reduction of the cingulum and Kuhnecone, as well as a subtle recumbency of the main cusps. The morphology of this taxon is enigmatic and the attribution to morganucodontids is tentative (Kielan-Jaworowska et al., 2004). The height proportions of cusps a-d, however, differ radically from Argentoconodon; the cusps are also more robust and less compressed. Other taxa from India such as Paikasigudodon (Prasad and Manhas, 2002), Indotherium (Yadagiri, 1984), and Indozostrodon (Datta and Das, 2001) are more clearly related to morganucodontids and megazostrodontids (Kielan-Jaworowska et al., 2004) or, as in Paikasigudodon, they are represented by elements not comparable with Argentoconodon and do not warrant close comparison.

Previous to this report, there was a single recognized triconodont genus in South America: Austrotriconodon Bonaparte, 1986a from the Late Cretaceous Los Alamitos Formation, Argentina. This genus is the sole member of the family Austrotriconodontidae Bonaparte, 1992 and is represented by isolated upper and lower teeth assigned to two different species: A. mckennai Bonaparte, 1986a and $A$. sepulvedai Bonaparte, 1992. Nevertheless, the atypical morphology of Austrotriconodon has prompted some doubts with regard to the molar nature of some elements attributed to this genus (KielanJaworowska et al., 2004) or their triconodontan affinities (Rougier et al., 2002). Argentoconodon shows many differences from the published elements of Austrotriconodon (Bonaparte, 1986a, 1990, 1992, 1994). First, lower molariforms of Austrotriconodon have crowns dominated by a principal cusp a, which is followed posteriorly by two small additional cusps $\mathrm{c}$ and $\mathrm{d}$. Cusp $\mathrm{c}$ can be slightly larger than cusp d but it is always very poorly developed. A rather robust cusp b is present in most of the described teeth of Austrotriconodon, and cingular remains can be 
identified on most teeth. This cusp arrangement and proportions of Austrotriconodon result in asymmetrical molariforms (if correctly identified) with cusps that decrease sharply in height posteriorly. The pattern in Austrotriconodon is complex in comparison to those of classic triconodont teeth in general and Argentoconodon in particular. We see no particular similarities linking Austrotriconodon and Argentoconodon.

The tooth described here is somewhat similar to the lower cheek teeth of the holotype of the Late Jurassic amphilestid Tendagurodon janenschi. As in our specimen, Tendagurodon has two roots with the three principal cusps $(\mathrm{a}-\mathrm{c})$ aligned and flanked by two smaller cingular cusps (e and d); it has little wear (only present on the apex of cusp a); and no cingula are present. Moreover, the cusp proportions are similar, although cusps $\mathrm{b}$ and $\mathrm{c}$ are less developed and not as separated from the principal cusp as in our specimen. On the other hand, it differs from the specimen described here by having more robust and not so vertically elongated cusps d, cusp e poorly differentiated, and a morphology that does not suggest an overlapping system.

The Late Jurassic amphilestid Triconolestes curvicuspis (Engelman and Callison, 1998) is similar to Argentoconodon in the distal curvature of the preserved main cusps (a and b), in the height proportion and separation between cusps $a$ and $b$, and in the presence of a single mesial cusp of median position that can be interpreted as cusp e (Kielan-Jaworowska et al. [2004] regarded the presence of cusp e as uncertain). Cusp e is proportionately smaller and cusp b is more robust in Argentoconodon, and the Patagonian tooth is far more compressed than that of Triconolestes. Despite tantalizing similarities, the holotype of Triconolestes is too fragmentary to allow definitive consideration of affinities between these two apparently very similar taxa.

Ichthyoconodon jaworowskorum (SigogneauRussell, 1995) from the Early Cretaceous of Morocco is an enigmatic triconodont (Sigogneau-Russell, 1995; Kielan-Jaworowska et al., 2004). Ichthyoconodon and Argentoconodon share deeply excavated recumbent cusps a and c, while cusp b is erect; the contact between teeth is accomplished by overlapping; and cusp d overhangs the root. Both taxa also have extremely compressed teeth, which led Sigogneau-Russell (1995) to consider other systematic alternatives for Ichthyoconodon, but she ultimately decided in favor of mammalian affinities; we agree with this determination. Ichthyoconodon seems to be more derived than Argentoconodon in the complete absence of any cingular cuspules, the subequal height of cusps a-c, and the loss of cusp e and further buccolingual compression.

\section{CONCLUSIONS}

Given the isolated nature of the specimen described here, we do not attempt to include it in a cladistic analysis; characters other than those from single isolated molars are needed for a more reliable systematic attribution. However, the features present in the molar of Argentoconodon allow us to recognize similarities with other known triconodonts, especially when compared to Triconolestes and Ichthyoconodon from the Late Jurassic Morrison Formation from the United States and the Early Cretaceous of Morocco, respectively. Thus, we think that the phylogenetic affinities of Argentoconodon lie among Jurassic triconodonts and their likely descendants of the Gondwanian Cretaceous. Argentoconodon lacks the autapomorphies that diagnose Triconodontidae and can be considered as part of the paraphyletic triconodont grade commonly regarded as amphilestids.

The similarities with Jurassic North American genera suggest that Argentoconodon might be a member of a broadly distributed Jurassic mammalian fauna, which would be in accord with the almost Pangaeic paleogeography of the Middle Jurassic. The ecumenical nature of the Jurassic fauna is reflected by most vertebrate groups from dinosaurs to mammals (Sereno et al., 1996; Rauhut, 2001). Nevertheless, Argentoconodon and other mammals such as the australosphenidans from the Cerro Cóndor (Rauhut et al., 2002; Martin and Rauhut, 2005; Forasiepi et al., 2004a, 2004b; Rougier et al., 2007) and the dryolestoids from several Patagonian localities (Bonaparte, 1990; 1992, 1994, 2002; Rougier et al., 2000, 2002; Rougier and 
Apesteguía, 2004) show a mosaic of characteristics that makes them peculiar and probably represent the beginning of an endemic Gondwanan mammal fauna, although the earlier representatives are not yet fully differentiated from the stock of Laurasian forms. This process would culminate in the Cretaceous with the strongly endemic faunas of the Late Cretaceous of South America and possibly Gondwana (Bonaparte, 1986a).

The Jurassic of India is illustrative of a tantalizing diversity of triconodont forms that seem to represent a wide range of lineages (Yadaggiri, 1984; Datta and Das, 1996, 2001; Prasad and Manhas, 2002) assimilated to the better known taxa described from the northern continents, but the morphology of the Indian triconodonts and that of Argentoconodon are atypical and likely represent major triconodont lineages yet poorly represented.

We have recently recovered an additional triconodont specimen represented by several disarticulated but associated elements that could correspond to this or a related triconodont taxon. New specimens from the Middle or Late Jurassic of Gondwana will be crucial for obtaining a comprehensive outline of the early stages of differentiation of Gondwanan/ South American fauna.

At present, Queso Rallado from the Cañadon Asfalto Formation is unique in Gondwana because of the number of specimens collected and the nature of the taxa found there. We are confident that Cañadon Asfalto still has much to offer.

\section{ACKNOWLEDGMENTS}

Fossil preparation, illustration, and part of the research have been funded by an NSF grant (DEB 0129061) and the Lampadian Foundation in support of a research project jointly developed by the AMNH and the Museo Paleontológico E. Feruglio (MEF). The support and encouragement of Dr. N. Cuneo, director of the MEF, Trelew, Argentina, have been particularly important; museum personnel have been critical to the success of this project and we are very grateful to them. We benefited from discussions of earlier versions of this paper with our col- leagues and friends E. Allin, J. Hopson, Z.-X. Luo, T.H. Rich, and J.R. Wible.

Fieldwork at the Queso Rallado quarry is demanding and tedious; we owe much to the hard work of students and volunteers from many places and institutions. We want to give special thanks to: Lucia Ballarino, Leandro Canesa, Magali Cardenas, Barbara Cariglino, Laura Chornogubsky, Kerin Cleason, Marcelo de la Fuente, Máximo Dellocca, Elenne Du Bois, Raul Gomez, Robert Hill, Agustina Lecuona, Paula Muzzopappa, Diego Pais, Diego Pol, Santiago Reuil, Juliana Sterli, Cecilia Stravis, Silvina de Valais, and Barbara Vera.

Our work has been greatly helped by the authorities of the Culture Ministry of Chubut Province and the primary school of Cerro Cóndor; they have provided the necessary permits and lodging in the school dependencies. Ricardo Farias and his family have been our hosts through the years; they have granted us access to their property and have served as a continuous stimulus for the development of vertebrate paleontology in the area.

\section{REFERENCES}

Bocchino, R.A. 1967. Luisiella inexculata gen. et sp. nov. (Pisces, Clupeiformes, Dussumieriidae) del Jurásico Superior de la provincia de Chubut, Argentina. Ameghiniana 5: 91-100.

Bonaparte, J.F. 1979. Dinosaurs: a Jurassic assemblage from Patagonia. Science 205: 1377-1399.

Bonaparte, J.F. 1986a. Sobre Mesungulatum houssayi y nuevos mamíferos cretácicos de Patagonia, Argentina. Congreso Argentino de Paleontología y Estratigrafía Actas 2: 63-95.

Bonaparte, J.F. 1986b. Les dinosaures (Carnosaures, Allosaures, Sauropodes, Cetiosaurides) du Jurassique moyen de Cerro Cóndor (Chubut, Argentine). Annales de Paléontologie 72: 247-289.

Bonaparte, J.F. 1990. New Late Cretaceous mammals from the Los Alamitos Formation, northern Patagonia. National Geographic Research 6: 63-93.

Bonaparte, J.F. 1992. Una nueva especie de Triconodonta (Mammalia), de la Formación Los Alamitos, Provincia de Río Negro y comentarios sobre su fauna de mamíferos. Ameghiniana 29: 99-110.

Bonaparte, J.F. 1994. Aproach to the significance of the Late Cretaceous mammals of South 
America. Berliner Geowissenchaftliche. Abhandlungen 13: 31-44.

Bonaparte, J.F. 2002. New Dryolestida (Theria) from the Late Cretaceous of Los Alamitos Formation, Argentina, and paleogeographical comments. Neues Jahrbuch für Geologie und Palaeontologie Abhandlungen 224: 339-371.

Bordas, A. 1942. Peces del Cretáceo del Río Chubut (Patagonia). Physis 19: 313-318.

Casamiquela, R.M. 1964. Estudios icnológicosproblemas y métodos de la icnología con aplicación al estudio de pisadas Mesozoicas (Reptilia, Mammalia) de la Patagonia, Pio IX: 229 pp. Buenos Aires: Colegio Industrial.

Chow, M., and T.H.V. Rich. 1984. A new triconodontan (Mammalia) from the Jurassic of China. Journal of Vertebrate Paleontology 4: 165-231.

Cifelli, R.L. 2001. Early mammalian radiations. Journal of Paleontology 75: 1214-1226.

Cifelli, R.L. 2002. Comodon Kretzoi and Kretzoi, 2000 replaces Phascolodon Simpson, 1925 (Mammalia) not Phascolodon Stein, 1859. Acta Paleontologica Polonica 47: 184.

Cifelli, R.L., and S.K. Madsen. 1998. Triconodont mammals from the medial Cretaceous of Utah. Journal of Vertebrate Paeontology 18: 403-411.

Cifelli, R.L., J.R. Wible, and F.A. Jenkins, Jr. 1998. Triconodont mammals from the Cloverly Formation (Lower Cretaceous), Montana and Wyoming. Journal of Vertebrate Paleontology 18: 237-241.

Crompton, A.W. 1971. The origin of the tribosphenic molar. Zoological Journal of the Linnean Society 50: 65-87.

Crompton, A.W. 1974. The dentitions and relationships of the southern African Triassic mammals, Erythrotherium parringtoni and Megazostrodon rudnerae. Bulletin of the British Museum (Natural History), Geology 24: 397-437.

Crompton, A.W., and F.A. Jenkins, Jr. 1968. Molar oclusion in Late Triassic mammals. Biological Reviews 43: 427-458.

Crompton, A.W., and F.A. Jenkins, Jr. 1979. Triconodonta. In J.A. Lillegraven, Z. KielanJaworowska and W.A. Clemens (editors), Mesozoic mammals: the first two-thirds of mammalian history, 74-90. Berkeley: University of California Press.

Datta, P.M., and D.P. Das. 1996. Discovery of the oldest fossil mammal from India. India Minerals 50: 217-222.

Datta, P.M., and D.P. Das. 2001. Indozostrodon simpsoni, gen. et sp. nov., an Early Jurassic megazostrodontid mammal from India. Journal of Vertebrate Paleontology 21: 528534.
Ellenberger, P. 1972. Contribution á la classification des pistes de Vertábrés du Trias: les types de Stromberg d'Afirque du Sud. Palaeovertebrata, Memoire Extraordinaire: 1-117.

Ellenberger, P. 1974. Contribution á la classification des pistes de Vertábrés du Trias: les types de Stromberg d'Afirque du Sud IIéme partie: le Stromberg Supérieur-1. le biome de la zone B/1 ou niveaux de Moyeni: ses biocenoses). Palaeovertebrata, Memoire Extraordinaire: $1-147$.

Ellenberger, P. 1975. L'explosion d'emographique de petits quadrupédes á allure de mamiféres dans le Stomberg Supérieur (Trias) d'Afrique du Sud: apercus sur leur origine au Permien (France et Karoo). Colloque International du Centre de la Recherche Scientifique 218: 409432.

Engelman, G.F., and G. Callison. 1998. Mammalian faunas of the Morrison Formation. Modern Geology 23: 343-379.

Figari, E., and S. Courtade. 1993. Evolución tectosedimentaria de la Cuenca Cañadón Asfalto, Chubut, Argentina. Actas XII Congreso Geológico Argentino y II Congreso de Exploración de Hidrocarburos (Mendoza) 1: 66-77.

Figari, E.G., S.F. Courtade, and L.A. Constantini. 1996. Stratigraphy and tectonics of the Cañadón Asfalto Basin, Lows of Gastre and Gan Gan, North of Chubut Province, Argentina. GeoResearch Forum 1-2: 359-368.

Forasiepi, A.M., A.G. Martinelli, and G.W. Rougier. 2004a. Un nuevo mamífero del Jurásico de Patagonia, Formación Cañadón Asfalto, Provincia del Chubut. Ameghiniana, Resúmenes XX Jornadas Argentinas de Paleontología de Vertebrados 41 suplemento 4: 46R.

Forasiepi, A.M., G.W. Rougier, and A.G. Martinelli. 2004b. A new mammal from the Jurassic Cañadon Asfalto Formation, Chubut Province (Argentina). Journal of Vertebrate Paleontology 24: 59A.

Hu, Y-M., J. Meng, Y. Wang, and C. Li. 2005. Large Mesozoic mammals fed on young dinosaurs. Nature 433: 149-152.

Hu, Y-M., Y. Wang, C-K. Li, and Z-X. Luo. 1998. Morphology of dentition and forelimb of Zhangheotherium. Vertebrata PalAsiatica 36: 102-125.

Hu, Y-M., Y. Wang, Z-X. Luo, and C-K. Li. 1997. A new symmetrodont mammal from China and its implications for mammalian evolution. Nature 390: 137-142.

Jenkins, F.A., Jr., and C.R. Schaff. 1988. The Early Cretaceous mammal Gobiconodon (Mammalia, Triconodonta) from the Cloverly Formation in 
Montana. Journal of Vertebrate Paleontology 8: 1-24

Ji, Q., Z-X. Luo, and A. Ji. 1999. A Chinese triconodont mammal and mosaic evolution of the mammalian skeleton. Nature 398: 326-330.

Kermack, K.A. 1963. The cranial structure of the triconodonts. Philosophcal Transactions of the Royal Society of London 246: 83-103.

Kermack, K.A., F. Mussett, and H.W. Rigney. 1973. The lower jaw of Morganucodon. Zoological Journal of the Linnean Society 53: 87-175.

Kielan-Jaworowska, Z., and D. Dashzeveg. 1998. Early Cretaceous amphilestid ('triconodont') mammals from Mongolia. Acta Paleontologica Polonica 43: 413-438.

Kielan-Jaworowska, Z., and P.P. Gambaryan. 1994. Postcranial anatomy and habits of Asian multituberculate mammals. Fossils and Strata 36: 1-92.

Kielan-Jaworowska, Z., R.L. Cifelli, and Z-X. Luo. 2004. Mammals from the Age of Dinosaurs. Origins, evolution, and structure. New York: Columbia University Press, 630 pp.

Kretzoi, M. and M. Kretzoi (editors). 2000. Fossilium catalogus 1: Animalia. Pars 137-Index generum et subgenerum mammalium. Leiden: Backhuys Publishers, 726 pp.

Krusat, G. 1989. Isolated molars of a triconodont and a symmetrodont (Mammalia) from the uppermost Jurassic of Portugal. Berliner Geowissenchaftliche 106: 277-289.

Leonardi, G. 1994. Annotated atlas of South American tetrapod footprints (Devonian to Holocene) with appendix on Mexico and Central America Brasília: Republica Federativa do Brasil, 246 pp.

Li, C-K., Y-Q. Wang, Y-M. Hu, and J. Meng. 2003. A new species of Gobiconodon (Triconodonta, Mammalia) and its implication for the age of Jehol Biota. Chinese Science Bulletin 48: 1129-1134.

Li, J-L., Y. Wang, Y-Q. Wang, and C-K. Li. 2000. A new family of primitive mammals from the Mesozoic of western Liaoning, China. Chinese Science Bulletin 45: 2545-2549. [In Chinese]

Luo, Z-X., R.C. Cifelli, and Z. Kielan-Jaworowska. 2001. Dual origin of tribosphenic mammals. Nature 409: 53-57.

Luo, Z-X., Q. Ji, J.R. Wible, and C. Yuan. 2003. An Early Cretaceous tribosphenic mammal and metatherian evolution. Science 302: 1934-1940.

Luo, Z-X., Z. Kielan-Jaworowska, and R.C. Cifelli. 2002. In quest for a phylogeny of Mesozoic mammals. Acta Palaeontologica Polonica 47: $1-78$.

Martin, T., and O.W.M. Rauhut. 2005. Mandible and dentition of Asfaltomylos patagonicus
(Australosphenida, Mammalia) and the evolution of tribosphenic teeth. Journal of Vertebrate Paleontology 25: 414-425.

Meng, J., Y-M. Hu, Y-Q. Wang, and C-K. Li. 2003. The ossified Meckel's cartilage and internal groove in Mesozoic mammaliaforms: implications to origin of the definitive mammalian middle ear. Zoological Journal of the Linnean Society 138: 431-448.

Mills, J.R.E. 1971. The dentition of Morganucodon. In D.M. Kermack and K.A. Kermack (editors), Early mammals. Zoological Journal of the Linnean Society 50: 29-63.

Musacchio, E.A. 1995. Estratigrafía y micropaloentología del Jurásico y el Cretácico en la comarca del Valle medio del Río Chubut, Argentina. Actas VI Congreso Argentino de Paleontología y Bioestratigrafía: 179-187.

Musacchio, E.A., C. Beros, and I. Pujana. 1990. Microfósiles continentales del Jurasico y el Cretácico en Chubut y su contribución a la bioestratigrafía de la Cuenca del Golfo de San Jorge, Argentina. In W. Volkheimer (editor), Bioestratigrafía de los sistemas regionales del Jurasico y el Cretácico de America del Sur 2: 355-383. Mendoza: CRICYT.

Olsen, P.E. 1980. Fossil great lakes of the Newark supergroup in New Jersey. In W. Manspeizer (editor), Field studies of New Jersey geology and guide to field trips: 352-398. New York: State Geological Association.

Olsen, P.E., D.V. Kent, H.D. Sues, C. Koeberl, H. Huber, A. Montanari, E.C. Rainforth, S.J. Fowell, M.J. Szajna, and B.W. Hartline. 2002. Ascent of dinosaurs linked to an iridium anomaly at the Triassic-Jurassic boundary. Science 296: 1305-1307.

Owen, R. 1871. Monograph of the fossil Mammalia of the Mesozoic formations. Monograph of the Paleontological Society 33 (for 1870): 1-115.

Patterson, B. 1956. Early Cretaceous mammals and the evolution of mammalian molar teeth. Fieldiana Geology 13: 1-105.

Prasad, G.V.R., and B.K. Manhas. 2002. Triconodont mammals from the Jurassic Kota Formation of India. Geodiversitas 24: 445-464.

Proserpio, C.A. 1987. Descripción geológica de la Hoja 44e, Valle General Racedo, Provincia del Chubut. Boletín de la Direccion Nacional de Mineria y Geologia 2001: 1-102.

Rainforth, E.C., and M.G. Lockley. 1996. Tracks of a diminutive dinosaur and hopping mammals from the Jurassic of North and South America. Bulletin of the Museum of Northern Arizona 60: 265-273.

Rasmussen, T.E., and G. Callison. 1981. A new species of triconodont mammal from the Upper 
Jurassic of Colorado. Journal of Paleontology 55: 628-634.

Rauhut, O.W.M. 2001. Herbivorous dinosaurs from the Late Jurassic (Kimmeridgian) of Guimarota, Portugal. Proceedings of the Geologists Association 112: 275-283.

Rauhut, O.W.M. 2003. Dentary of Patagosaurus (Sauropoda) from the Middle Jurassic of Patagonia. Ameghiniana 40: 425-432.

Rauhut, O.W.M., T. Martin, E. Ortiz-Jaureguizar, and P. Puerta. 2002. A Jurassic mammal from South America. Nature 416: 165-168.

Rich, T.H., P. Vickers-Rich, O. Gimenez, R. Cúneo, P. Puerta, and P. Vacca. 1999. A new sauropod dinosaur from Chubut Province, Argentina. In Y. Tomida, T.H. Rich and P. Vickers-Rich (editors), Proceedings of the Second Gondwana Dinosaur Symposium: 61-84. Tokyo: National Science Museum Monographs.

Rich, T.H., T.F. Flannery, P. Trusler, L. Kool, N.A. van Klaveren, and P. Vickers-Rich. 2002. Evidence that monotremes and ausktribosphenids are not sister groups. Journal of Vertebrate Paleontology 22: 466-469.

Rougier, G.W., and Apesteguia, S.. 2004. The mesozoic radiation of dryolestoids in South America, dental and cranial evidence. Journal of Vertebrate Paleontology 24: 106A.

Rougier, G.W., A.M. Forasiepi, A.G. Martineli, and M.J. Novacek. 2007. New Jurassic mammals from Patagonia, Argentina: a reappraisal of Australosphenidan morphology and interrelationships. American Museum Novitates 3566: 1-54.

Rougier, G.W., S. Isaji, and M. Manabe. 1999. An Early Cretaceous Japanese triconodont and a revision of triconodont phylogeny. Journal of Vertebrate Paleontology 19: 72A.

Rougier, G.W., S. Isaji, and M. Manabe. In press. An Early Cretaceous Mammal from the Kuwajima Formation (Tetori Group), Japan and a reassessment of "triconodont" phylogeny. Annals of the Carnegie Museum of Natural History: 110 pp. 7 figs.

Rougier, G.W., M.J. Novacek, R. Pascual, R.V. Hill, and P.F. Puerta. 2001. Mammalian petrosals from the Late Cretaceous of South America: implications for the evolution of the mammalian ear region. Journal of Vertebrate Paleontology 21(suppl. 3): 68.

Rougier, G.W., B.K. Spurlin, and P.K. Kik. 2003. A new specimen of Eurylambda aequicrurius and considerations on "symmetrodont" dentition and relationships. American Museum Novitates 3398: 1-15.

Rougier, G.W., J.R. Wible, and J.A. Hopson. 1996. Basicranial anatomy of Priacodon fruitaensis
(Triconodontidae, Mammalia) from the Late Jurassic of Colorado, and a reappraisal of mammaliaform interrelationships. American Museum Novitates 3183: 1-38.

Rougier, G.W., J.R. Wible, and M.J. Novacek. 1998. Implications of Deltatheridium specimens for early marsupial history. Nature 396: 459-463.

Rougier, G.W., M.J. Novacek, M.C. McKenna, and J.R. Wible. 2001. Gobiconodonts from the Early Cretaceous of Oshih (Ashile), Mongolia. American Museum Novitates 3348: 1-30.

Rougier, G.W., M.J. Novacek, D. Pol, A.M. Forasiepi, P. Muzzopappa, J. Sterli, and B. Cariglino. 2002. La fauna mamaliana de la Formación La Colonia (Cretácico Superior), Chubut: afinidades y diversidad. Ameghiniana, Resúmenes XVIII Jornadas Argentinas de Paleontología 39: 16R.

Rowe, T.B. 1988. Definition, diagnosis and origin of Mammalia. Journal of Vertebrate Paleontology 8: 241-264.

Rowe, T.B. 1993. Phylogenetic systematics and the early history of mammals. In F.S. Szalay, M.J. Novacek and M.C. McKenna (editors), Mammal phylogeny, Mesozoic differentiation, multituberculates, monotremes, early therians and marsupials: 129-145. New York: SpringerVerlag.

Sereno, P.C., D.B. Dutheil, M. Iarochene, H.C.E. Larsson, G. Lyon, P.M. Magwene, C.A. Sidor, D.J. Varricchio, and J.A. Wilson. 1996. Predatory dinosaurs from the Sahara and Late Cretaceous faunal differentiation. Science 272: 986-991.

Sigogneau-Russell, D. 1983. Caractéristiques de la fauna mammaliene du Rhétien de SaintNicholas-de-Port (Meuste-et-Moselle). Bulletin d'Information des Géologues du Bassin de Paris 20: 51-53.

Sigogneau-Russell, D. 1995. Two possibly aquatic triconodont mammals from the Early Cretaceous of Morocco. Bulletin du Muséum National dHistorie Naturelle, Paris, sér. 4 16C: 291-312.

Sigogneau-Russell, D. 2003. Diversity of triconodont mammals from the Early Cretaceous of North Africa-affinities of the amphilestids. Paleovertebrata 32: 27-55.

Sigogneau-Russell, D., and P. Godefroit. 1997. A primitive docodont (Mammalia) from the Upper Triassic of France and the possible therian affinities of the order. Comptes Rendus de l'Académie des Sciences 324: 135-140.

Silva Nieto, D.G., N. Cabalero, and F.M. Salani. 2003. Estratigrafía de la Formación Cañadón Asfalto (Jurásico Superior), Provincia del 
Chubut, Argentina. Ameghiniana, Resúmenes Primer Simposio Argentino del Jurásico 40: 46R. Simpson, G.G. 1925a. Mesozoic Mammalia. American Triconodonts. Part I. American Journal of Science 10: 145-165.

Simpson, G.G. 1925b. Mesozoic Mammalia. American Triconodonts. Part II. American Journal of Science 10: 334-358.

Simpson, G.G. 1928. A catalogue of the Mesozoic Mammalia in the Geological Department of the British Museum. London: Oxford University Press, $125 \mathrm{pp}$.

Simpson, G.G. 1929. American Mesozoic Mammalia. Memoirs of the Peabody Museum of Yale University 3: 1-171.

Starck, D. 1995. Lehrbuch der Spezielle Zoologie. Band II. Wirbeltiere Teil 5, 1-2: 1241 pp. Säugetiere, Jena: Gustav Fischer Verlag.

Stipanicic, P.N., F. Rodrigo, O.L. Baulíes, and C.G. Martínez. 1968. Las formaciones precenomanianas en el denominado macizo Nordpatagónico y regiones adyacentes. Revista de la Asociación Geológica Argentina 23: 67-98.

Tasch, P., and W. Volkheimer. 1970. Jurassic conchostracans from Patagonia. University of Kansas Paleontological Contributions 50: $1-23$.
Trofimov, B.A. 1978. The first triconodonts (Mammalia, Triconodonta) from Mongolia. Doklady Akademii Nauk SSSR 251: 209212.

Turner, J.C. 1983. Decripción Geológica de la Hoja 44d, Colan Conhué, Provincia del Chubut. Servicio Geológico Nacional. Ministerio de Economía de Estado de Industria y Minería Subsecretaría de Minería, Boletín 197. Buenos Aires.

Vandebroek, G. 1964. Recherches sur l'origine des Mammifères. Annales de la Société Royale Zoologique de Belgique 94: 117-160.

Wang, J-Q., Y-H. Hu, J. Meng, and C-K. Li. 2001. An ossified Meckel's cartilage in two Cretaceous mammals and origin of the mammalian middle ear. Science 294: 357-361.

Woodburne, M.O. 2003. Monotremes as pretribosphenic mammals. Journal of Mammalian Evolution 10: 195-248.

Woodburne, M.O., T.H. Rich, and M.S. Springer. 2003. The evolution of tribospheny and the antiquity of mammalian clades. Molecular Phylogeny and Evolution 28: 360-385.

Yadaggiri, P. 1984. New symmetrodonts from the Kota Formation. Journal of the Geological Society of India 25: 512-521. 


\section{APPENDIX 1}

Measurements of AGENTOCONDON FARIASORUM, IN MILLIMETERS

Use figure 5 as a reference.

\begin{tabular}{lcl}
\hline \hline & MPEF-PV 1877 & \multicolumn{1}{c}{ Measurement } \\
\hline 1 & 2.850 & Molar length \\
2 & 0.550 & Height of cusp e \\
3 & 0.925 & Anterior height of cups b \\
4 & 0.450 & Posterior height of cusp b \\
5 & 1.050 & Anterior height of cups a \\
6 & 1.075 & Posterior height of cusp a \\
7 & 0.675 & Anterior height of cups c \\
8 & 0.825 & Posterior height of cusp c \\
9 & 0.575 & Height of cusp d \\
\hline
\end{tabular}

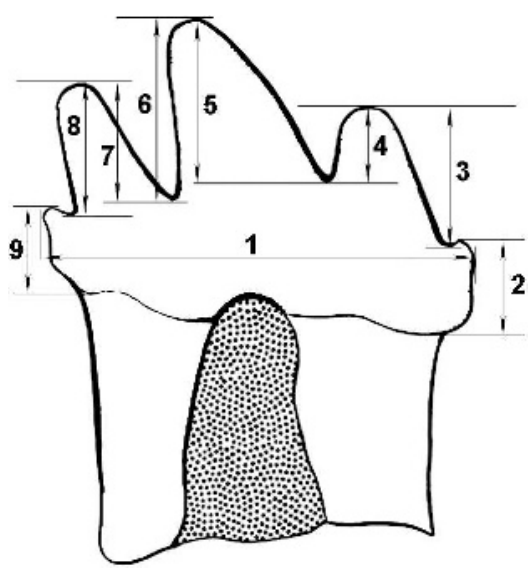

Fig. 5. Measurements of the type specimens of Argentoconodon fariasorum n.gen. et sp., MPEF PV 1877. Numbers refer to measurements given in appendix 1 . 


Complete lists of all issues of the Novitates and the Bulletin are available at World Wide Web site http://library.amnh.org/pubs. Inquire about ordering printed copies via e-mail from scipubs@amnh.org or via standard mail from: American Museum of Natural History, Library-Scientific Publications, Central Park West at 79th St., New York, NY 10024. TEL: (212) 769-5545. FAX: (212) 769-5009.

@ This paper meets the requirements of ANSI/NISO Z39.48-1992 (Permanence of Paper). 